\title{
WILLIAM JAMES ON THE PRAGMATIC CONCEPTION OF TRUTH AND HUMAN KNOWLEDGE: A REFORMATIONAL REFLECTION
}

\author{
Jadi Sampurna Lima \\ Sekolah Tinggi Teologi Reformed Injili Internasional \\ Korespondensi: yadislima@gmail.com
}

\begin{abstract}
At a glance, William James' conception of truth in epistemology, especially in its critique of Modernism's a-temporal, a-contextual, and absolutist conception of truth sounds very similar with a critique from Herman Dooyeweerd of the Reformational tradition. In this article, I would show what those similarities are and how the two systems are radically different. This research may be significant for Pragmatism is widely known and accepted in the late $20^{\text {th }}$ century and well into the $21^{\text {st }}$ century. Pragmatism is quite successful in grounding the elitist and abstract discourse of the academia to its daily contexts.
\end{abstract}

KEYWORDS: William James; Herman Dooyeweerd; Truth; Pragmatism; Refomational Epistemology.

ABSTRAK: Sekilas konsep William James tentang kebenaran dalam konteks epistemologi, khususnya dalam kritik yang ia tujukan kepada konsep modern tentang kebenaran yang a-temporal, a-kontekstual, dan absolutis terdengar mirip dengan kritik atas hal yang sama oleh Herman Dooyeweerd dari tradisi Reformasional. Dalam artikel ini penulis akan menunjukkan hal-hal apa saja di antara keduanya yang serupa dan dalam hal apa saja keduanya berbeda secara radikal. Riset ini dapat berguna mengingat luas dan pentingnya pengaruh Pragmatisme yang tak dapat diremehkan di dalam dunia abad ke-20 dan 21. Pragmatisme cukup sukses dalam mendaratkan pergulatan akademis modern atas pengetahuan manusia yang pada masa Enlightenment yang seringkali cenderung abstrak dan elitis terhadap konteks kesehariannya.

KATA KUNCI: William James; Herman Dooyeweerd; Kebenaran; Pragmatisme; 
Epistemologi Reformasional.

\section{Introduction}

In a reflection on the influence of Pragmatism in the North American Evangelicals' refusal to think deep, Os Guinness points to William James as one of the culprits. He writes,

[James] held that religious beliefs were only true because of their consequences for human behavior, not because of their philosophical claims. Truth, in other words, was not absolute. It was an attribute that beliefs acquired as they were worked out in practice. ${ }^{1}$

Like Guinness, many other thinkers are also very critical to the pragmatic conception of Truth. ${ }^{2}$ It is considered as making the conception of Truth 'too subjective'. ${ }^{3}$ In this paper, however, I will try to be more appreciative to James. I will try to make use of James' conception of Truth as well as his reflections on it to enrich our understanding of truth beyond mere 'accurate correlation to reality'. Furthermore, in order to 'examine everything carefully' and 'hold fast to that which is good' (1 Thessalonians 5:21) I will also evaluate James conception of truth to 'separate the chaff from the wheat'. The evaluation will be done with a help from a Dutch Calvinistic philosopher, Herman Dooyeweerd. This paper is a Reformational reflection on William James' conception of Truth and how it can be useful for the service to the King Jesus.

At the first glance, William James' concept of Truth in the context of human knowledge, especially his critique on the Modernist conception of a-temporal, a-contextual, Absolute Truth sounds similar in many ways with Reformational critique by Dooyeweerd. I will show in which ways they are similar and in what ways they are incompatible. This research can be significant because Pragmatist's conception of Truth provides a very useful framework to relate human knowledge to everyday practices. They are also widely known and used in contemporary (or postmodern) era as shown in the work of Rorty. ${ }^{4}$

\footnotetext{
1 Os Guinness, Fit Bodies, Fat Minds: Why Evangelicals don't Think and What to do about It (Grand Rapids: Baker Books, 1994) 55.

2 See James Mark Baldwin, ed. Dictionary of Philosophy and Psychology, v.2. (London: MacMillan\&Co., 1905). William James, of course, is not the only one who proposed a pragmatic conception of Truth. There are other important pragmatic thinkers like C.S. Peirce and John Dewey.

3 See Frederick Schmitt, Truth: A Primer (Boulder: Westview, 1995) and John Nolt, "Truth as an Epistemic Ideal," Journal of Philosophical Logic Vol. 37, No.3 (2008): 203-237.

4 See Richard Rorty, Philosophy and the Mirror of Nature (New Jersey: Princeton Univ. Press, 1979) 10, where he follows James notion of Truth as 'what is better for us to believe' rather than 'the accurate
} 
My research question in this article is: "In what ways William James' conception of Truth comparable to that of Dooyeweerd?" I will answer those questions in four steps: 1) In the background of James' analysis of Truth, what is his critique on current conception of Truth and human knowledge? 2) What is James' conception of Truth? 3) What is Dooyeweerd's conception of Truth? 4) How do they compare?

\section{William James' New Name for Old Ways of Thinking about Truth}

We will consider William James (1842-1910) concept of Truth and Reality in the context of human knowledge. His conception is controversial in his time, especially in North America, before the anti-correspondence and anti-realism movements widely accepted. I will divide the description into two parts, namely James' description on Truth(s) and Reality. Then in the last sub-section I give some general remarks on polemic regarding James' position.

\section{Truth}

Similar to the Intellectualists who held correspondence theory of knowledge, William James defines 'truth' as 'property of certain of our ideas,' namely their 'agreement' with 'reality'. ${ }^{5}$ There is nothing new or controversial about this definition. The quarrel began when he tried to be more rigorous in defining what 'agreement with reality' really is. Basically James sees that their ideas of 'agreement' and 'reality' to be too naïve for we don't have any valid means to compare various kinds of knowledge to the (unmediated) 'reality out there.' 6 To put it in Thomas Nagel's term, we don't know 'what is it like to be a bat.'

William James criticizes those he called as 'Intellectualists' in their ideas that 'agreement to reality' means our 'copying' of reality out there. In most cases, it is impossible to have an exact copy of reality in our minds. At most we only have a limited approximation of the external objects or happenings. In this case, definition of 'agreement to reality' as 'copying

\footnotetext{
representation of reality'.

5 He wrote in "Lecture VI: Pragmatism's Conception of Truth" in his book Pragmatism: A New Name for Some Old Ways of Thinking (New York: Longmans, 1907), "Truth, as any dictionary will tell you, is a property of certain of our ideas. It means their 'agreement,' as falsity means their disagreement, with 'reality.' Pragmatists and intellectualists both accept this definition as a matter of course. They begin to quarrel only after the question is raised as to what may precisely be meant by the term 'agreement,' and what by the term 'reality,' when reality is taken as something for our ideas to agree with."

6 Douglas McDermid, The Varieties of Pragmatism: Truth, Realism, and Knowledge from James to Rorty (New York: Continuum, 2006), 18-20.

7 See Rorty's quote of Thomas Nagel's article, "What Is It Like to be a Bat?" in the first chapter of his book: Richard Rorty, Philosophy and the Mirror of Nature (New jersey: Princeton Univ. Press, 1979), 28-29.
} 
reality' becomes senseless. James gives an example of 'copying' the idea of a watch into our mind. In this case we will never have an exact copy of a watch; firstly, unless we are a watchmaker or an expert in the art, we would not have any idea of the exact mechanism involves in the watch. We only 'see' the watch according to its 'function' of keeping the time. ${ }^{8}$ We only have a 'pointer' - not a copy of the watch inside our mind. Secondly, even watch experts themselves cannot have an exact copy of the watch in every layer of details. There will be more to be known in the watch than what is already known by the observer.

James also attacked the idea of 'agreement' as "what God means that we ought to think about that object." ${ }^{\prime 9}$ For James, this idea leads us nowhere. Those who think this way see Truth as possession; that is the end of it. While for the Pragmatists, truth is not an end in itself; it must have a 'cash value'. It must be useful to make a "concrete difference in anyone's actual life."10 Maybe we can see a lot of truth in Bertrand Russell's famous suggestion to see Karl Marx as the first exponent of pragmatism, quoting his words, "Philosophers have only interpreted the world in various ways, but the real task is to alter it."11 The pragmatists are not satisfied with accuracy of the truth, but they go further to consider seriously what kind of differences it can possibly make. In other words, they are more interested to what we can do with the truth, rather than whether it corresponds to reality, whatever it may be.

This practical consideration determines his criteria for truthfulness of an idea for James:

TRUE IDEAS ARE THOSE THAT WE CAN ASSIMILATE, VALIDATE, CORROBORATE AND VERIFY. FALSE IDEAS ARE THOSE THAT WE CANNOT. That is the practical difference it makes to us to have true ideas; that, therefore, is the meaning of truth, for it is all that truth is known-as." ${ }^{12}$

We can see that his idea of truth is not inert-static, but as a dynamic happening that inter-related to the rest of our life. Truth happens to an idea; it is not a stagnant property inherent in it. An idea becomes true by verification and validation process. James said that, "Its validity is the process of its valid-ATION." ${ }^{13}$ This process signifies a certain practical consequences of that

\footnotetext{
8 William James, "Pragmatism's Conception of Truth," in The Nature of Truth: Classic and Contemporary Perspectives, ed. Michael P. Lynch (Cambridge: MIT Press, 2001), 212.

9 Ibid.

10 Ibid.

11 Quoted in Nicholas Rescher, Realistic Pragmatism: An Introduction to Pragmatic Philosophy (Albany: Suny Press, 2000), 2.

12 James, "Pragmatism's Conception of Truth," The Nature of Truth, 212-213.

13 Ibid. 213.
} 
idea. In this way we can see that the Pragmatist conception of Truth does not separate the realm of Truth with the realm of everyday happenings (praxis). To picture Truth, James used a metaphor of snowball formation as the product of several factors.

Truth is the function of the beliefs that start and terminate among them. The case is like a snowball's growth, due as it is to the distribution of the snow in the one hand, and to the successive pushes of the boys on the other, with these factors co-determining each other incessantly. ${ }^{14}$

It is clear to us that what James values in the Truth is not in its faithfulness or accuracy; because he sees the Truth as being made. It's a dynamic becomingnever loose touch with its surroundings, i.e. ordinary human experience.

For James everything is always interconnected with everything, so there is no stand-alone 'abstract-Truth' to begin with. Truth of an idea emerges from facts and will dissolves back into facts.

There can be no difference anywhere that doesn't make a difference elsewhere - no difference in abstract truth that doesn't express itself in a difference in concrete fact and in conduct consequent upon that fact imposed on somebody, somehow, somewhere, and somewhen [sic.]. ${ }^{15}$

To summarize a little bit, we can say that for James 'Truth' (or 'truths' in plural and with small ' $\mathrm{T}$ ' - as he preferred) is/are: 1) What concrete difference will its being true make in any one's actual life" - and difference in experiences if it is false. That is, "what is the cash-value?" 2) "Those that we can assimilate, validate, corroborate and verify" while 'false ideas' are "those that we cannot assimilate, validate, corroborate and verify" 3) They are means. They are not an end in themselves, they serve other (useful) ends - "we live in a world of realities that can be infinitely useful or infinitely harmful." 4) Something useful. "It is useful because it is true; it is true because it is useful." 5) Whatever idea starts the verification-process, useful is the name for its completed function in experience. 6) Always conditional. Although Truth, singular with a capital ' $\mathrm{T}$ ' claims abstractly to be recognized, concrete truths need to be recognized only where their recognition is expedient. 7) Something exist in rebus -in other words: truths do not stand alone. 'The true' is only the expedient in the way of our thinking, just as 'the right' is only the expedient in the way of our behaving. ${ }^{16} 8$ ) It goes in a recycle fashion with Facts.

14 William James, "Pragmatism's Conception of Truth" in Pragmatism: A New Name for Some Old Ways of Thinking (New York: Barnes \& Nobles Books, 2003), 99.

15 Cheryl Misak, "There Can Be No Difference Anywhere That Doesn't Make a Difference Elsewhere," in Transactions of the Charles S. Peirce Society 54, no. 3 (2018): 417-29. https://www.jstor.org/stable/10.2979/ trancharpeirsoc.54.3.09.

16 James, "Pragmatism's Conception of Truth," 222. 
"Truth is the function of the beliefs that start and terminate among facts." Truths emerge from facts, dip forward into facts again - add something to it, which facts again create/reveal new truths, and so on indefinitely; e.g. in the history of science, theories and discoveries come and go.

\section{Reality}

Basically James uses a broad definition of reality. First, he equates reality as 'concrete facts' or 'objects'. It is either things of common sense sensibly present, or common sense relations (such as dates, places, or distances). ${ }^{17}$ So reality is both the 'external objects' and the 'internal minds' that 'conceived' them. Against the impractical verification standard of the Intellectualists on the presence of the external objects, he argues for the validity of waiving complete verification in favor of practicality of everyday life (as long as nobody objects). ${ }^{18}$ Extending further the definition, he says, "Realities are relations among purely mental ideas." 19 Later he also includes the whole body of other truths already in our possession. ${ }^{20}$ Our new ideas must take account of this older body of truths. He emphasizes that the social construction processes of the idea and the belief formation about our world. The ideas have no rigid 'right or wrong' in themselves, but once they have been established as a consensus, then we have to use it consistently. ${ }^{21}$

Some of his followers, Rorty is one of them, sees James as an anti-realist in his ontology. ${ }^{22}$ But, it seems not the case with him. ${ }^{23}$ He never denies the important existence of reality other than the knower. The difference between the Pragmatists and the Intellectualists, for James, is not in whether reality really exist or not, but in its definition and conception. ${ }^{24} \mathrm{~W}$. Kunne sees that even Dewey (one of James early followers) was not concern with denying, but understanding the characterization of truth in terms of agreement or correspondence..$^{25}$

\section{Polemic}

James was aware of the controversy regarding his novel ideas. He mentioned

Ibid., 215 .

8 Ibid., 215-216.

19 Ibid., 216.

20 lbid., 217.

21 Ibid., 218-219.

22 Richard Rorty, Objectivity, Relativism, and Truth (Cambridge: Cambridge Univ. Press, 1991), 22-23.

23 Douglas McDermid, The Varieties of Pragmatism: Truth, Realism, and Knowledge from James to Rorty (New York: Continuum, 2006), 2.

24 William James, Pragmatism: A New Name for Some Old Ways of Thinking in The Works of William James I. (Harvard: Harvard Univ. Press, 1975), 96.

25 Wolfgang Kunne, Conceptions of Truth (Oxford: Clarendon Press, 2003), 172. 
some of the attacks launched by the Intellectualists on his conception on Truth(s). They said that: 1) The pragmatists are 'putting their carts before the horse' in making truth's being reside in verification-process. ${ }^{26}$ 2) They desecrate the notion of Truth: it should be free from practical interests or personal reasons. ${ }^{27} 3$ ) They are limiting verification to the lowest material utilities. $^{28} 4$ ) They are destroying all objective standards: put foolishness and wisdom on one level-for they use 'satisfaction' as the criteria for truth. ${ }^{29}$

James answers these criticisms by saying that, 1) Rationalists' Truth is irrelevant. It belongs to epistemological realm, unable to exist in the world of facts. I think, this one is an offensive counter-attack that not really answer the rationalists' objection about his 'cart-before-the-horse' verification processes, although I agree with James' in saying that the Absolute-Rationalistic-Truth are hard to be made relevant to everyday factual experiences. 2) Rationalists' propositional Truth is trivial. They shed tears on abstract beauty but unable to recognize this quality when meeting them in the street. ${ }^{30}$

My remarks on James' first answer should be relevant to this one. I think his mocking of the Rationalist's emotional fantasy as trivial has some truth in it. 'Truth for the sake of Truth' slogan-like the 'Art for the sake of Art' - doesn't make much sense for it is always a thinker who thinks behind the thoughts. More on this matter later, on the chapter about Dooyeweerd's notion on Truth. 3) The Rationalists are looking backward to a past eternity, while the Pragmatists are looking forward to the future. ${ }^{31}$ It is clear that James was using modern Western man's sympathy toward everything new - and rather antipathy toward everything obsolete - as his rhetorical strategy here. There are lack of argumentations here, for instance, what's so special about heading the future so that it must be better than 'looking backward to a past eternity'? 4) The idea of 'copying' Absolute Truth is ridiculous. How can the Eternal Truth impose to man the 'duty' to copy itself? ${ }^{32}$

\section{Dooyeweerd's Conception of Truth}

Although Herman Dooyeweerd (1894-1977) was aware of William James' work he did not say much about it. In his magnum opus "A New Critique of Theoretical Thought," Dooyeweerd only mention James briefly in the discussion about 'economy of thought'-economical anticipation in the

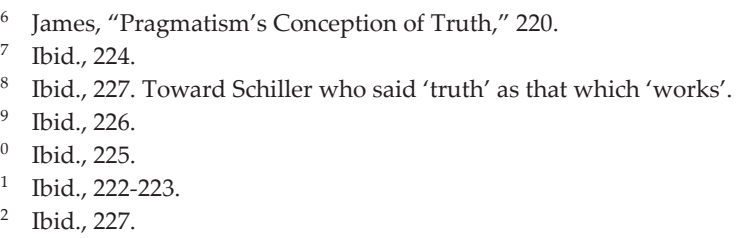


modality of logical-analytical. ${ }^{33}$ Dooyeweerd did not mention James at all in his exposition on Truth. But I think their similarity regarding Truth goes deeper than that brief citation.

In this article I will only discuss Dooyeweerd's treatment on Truth in $A$ New Critique of Theoretical Thought (NCTT) Vol. I. chapter II.5 and NCTT Vol. II. chapter IV.3 together with some additional remarks made by contemporary Reformational thinkers, e.g. Henk Geertsema and Lambert Zuidervaart.

\section{Truth, Reality, Human Being, and God}

Dooyeweerd's definition of Truth require much explanations. He differentiates between transcendental (a priori) structure of truth and theoretical truth. Here is the quote for the first one:

According to its transcendental a priori dimension truth is: the accordance between subjective a priori knowledge enclosed by the temporal horizons, as expressed in a priori judgments, and the a priori structural laws of human experiences within this temporal horizon. The latter is open (as to its law and subject-sides) to the light of transcendent truth in Christ. ${ }^{34}$

While the theoretical truth is defined, in relation to the modal horizon, as:

The correspondence of the subjective a priori meaning-synthesis as to its intentional meaning with the modal-structure of the "Gegenstand" of theoretical thought. This synthesis is actual in our a priori theoretical insight, and is expressed in theoretical a priori judgments. The modal "Gegenstand" is included in its all-sided inter-modal coherence within the temporal horizon. This coherence exists both in the foundational and in the transcendental direction of time and is dependent on the transcendent fullness of the meaning of Truth..$^{35}$

Dooyeweerd's discussion on Truth is related to his view on human knowledge, reality, and God. For Dooyeweerd, epistemology is not about "what is knowledge?" - his question is, "how theoretical knowledge is possible?" He writes,

The fundamental question of epistemology should, consequently, not be formulated: How is universally valid experience of the 'Gegenstand' (i.e. the resistant to the logical function of thought) possible? The primodial question should be: What do we abstract from the real datum of experience in the fundamental anti-thetical relation of theoretical thought which gives rise to the problem of the 'Gegenstand'? And only in an unbreakable coherence with this primodial question should the second problem be raised: How

33 Herman Dooyeweerd, A New Critique of Theoretical Thought Vol. 2: The General Theory of the Modal Spheres, tran. David H. Freeman and H. de Jongste (New York: Mellen, 1997), 123.

34 Ibid., 573.

35 lbid., 575 . 
can the theoretical antithesis between the logical function of knowledge and its non-logical 'Gegenstand' be reconciled by an inter-modal theoretical meaning-synthesis? ${ }^{36}$

His discussion on truth is 'perspectival', not in the Nietzschean sense of subjective-personal-ness, but in the sense that it is structured in many layers of horizons (or better, in Lambert Zuidervaart's term: 'horizonal'). ${ }^{37}$ Truth, as also the case with human experience, structured in four levels or horizons: 1) communal structure of its religious root, 2) cosmic time as the bond that unifies the 15 modal-aspects, 3) the diversity of modal-aspects themselves, 4) the dimension of the structures of individuality. ${ }^{38}$

According to L. Zuidervaart, Dooyeweerd's prolegomena on the condition of theoretical knowing centered around three main questions: ${ }^{39}$ (1) "[W]hat makes it possible for theorists to engage in abstraction from ordinary experience and from the structures of creation, which people ordinarily experience in a holistic fashion?" (2) "What makes it possible for theorists to achieve a synthesis between those aspects of experience and of creation which must stand in opposition when theorizing occurs?" (3) "What makes it possible for theorists to engage in ... theory-transcending and critical self-reflection?" 40 The second of these questions poses the "problem of intermodal synthesis," which Dooyeweerd now identifies as the central problem of theoretical knowledge. His solution for this consists of two stages: First, he distinguishes and relates three types of epistemic coherence: meaning-systasis (temporal-coherence, ed.), logical synthesis, and intermodal meaning-synthesis. Second, he claims that all three types, including intermodal synthesis, are made possible by and informed by a radical unity that exceeds all three. ${ }^{41}$ This unity of structure is fundamentally religious, that 'life is religion': no knowledge or truth can be religiously neutral, including the theoretical/philosophical ones; it is never 'purely theoretical with respect to its meaning' ${ }^{42}$

Over against the view of knowledge and truth as correspondence of our knowledge to an independent 'facts out there', or 'reality in itself' as opposed to 'as it is appear to us', Dooyeweerd's view can be summarized as: 1) Knowing is not corresponds to being because there is no 'being in itself'.

36 Ibid., 433-434.

37 Lambert Zuidervaart, After Dooyeweerd: Truth in Reformational Philosophy (Toronto: ICS, 2008), 6.

38 Dooyeweerd, A New Critique of Theoretical Thought Vol. 2, 552-559.

39 Zuidervaart, After Dooyeweerd, 6-7.

40 Lambert Zuidervaart, Religion, Truth, and Social Transformation: Essays in Reformational Philosophy (Montreal: McGill-Queen's, 2016), 31.

$41 \quad$ Ibid., 55.

42 Herman Dooyeweerd, A New Critique of Theoretical Thought Vol. 1: The Necessary Presuppositions of Philosophy, tran. David H. Freeman and William S. Young (New York: Mellen, 1997), 148-149. 
Being encompasses knowing. Being known is part of the being. 2) The idea of 'Ding an sich' is itself an abstraction. Not a factual reality independent to human knowing. So, there is no 'absolute-independent world' and being known is integral to being there. 3) There is no absolute knowledge. Logical aspect is inter-related to other aspects in reality. ${ }^{43}$

But he does not dismiss the concept of 'truth as correspondence' altogether. "Dooyeweerd does understand truth in terms of correspondence between subjective insight and what is there to be known,"44 although the latter is not an independent entity altogether. He does not separate 'thinking subject' and 'object' of observation as two totally independent entities; those are on the reality and the observer, over against Kantian split between Ding an sich and phenomena (as appear to us); or apriori vs. aposteriori. Dooyeweerd emphasizes the limitation (situatedness, temporality, and perpectiveness) of human knower without starting everything from the thinking-self. Dooyeweerd argues that human knowledge will always be mediated. It won't be able to grasp the Ding an sich directly. He writes,

[...] all human experience is bound to some horizon which makes this experience possible. [...] This horizon of experience is not a subjective cadre within which reality appears to us only in a phenomenal shape (determined by a supposedly creative synthesis) and behind which the fundamentally in-experienceable dimensions of some "thing in itself" ("Ding an sich") are situated. ${ }^{45}$

Instead, Dooyeweerd emphasizes the paradigm of creational structure as meaning to avoid the split between human observer and the 'external' reality he observes.

It is rather the a priori meaning-structure of our cosmos itself in its dependence on the central religious sphere of the creation and in subjection to the Divine Origin of all things. The horizon of human experience is that of our 'earthly' cosmos as it is given in the Divine order of the creation. ${ }^{46}$

In other words, created reality is inter-related in very complex modalities structures which include human knower in it - where knowing is just one of many functions. Therefore, truth is not 'adaequatio intellectus et rei' but broader than that, it is our proper response toward the law that structured reality, or better, toward God as the Origin of Creation.

In Dooyeweerd's terms, although significantly modified, this means that truth involves an "accordance" between human responses to "modal laws" and

43 Henk G. Geertsema, “Dooyeweerd on Knowledge and Truth," in Ways of Knowing in Concert (Sioux Center: Dordt College Press, 2005), 85-100.

44 Ibid.

45 Dooyeweerd, A New Critique of Theoretical Thought Vol. 2, 548.

46 Ibid. 
the direction that the results of these responses take-the direction they take both with respect to the "central religious law" and with respect to the God who calls creation into existence and who meets human beings from an inexpressible future. ${ }^{47}$

Our knowing, being truth or untruth, is not mere vain debate about petty accuracies - but it is about closing or disclosing reality; it is about being ethical, or unethical; it is about being loving, or not destroying toward reality. We will see more about the relation of truth, normativity of God's law in creation, and our response in subsequent part below.

\section{Metaphor Analysis}

Comparing Dooyeweerd's view of Truth to the proponent of Correspondence Theory we can clearly see that they are using different metaphors. Standing in Dooyeweerdian tradition regarding Truth, Henk Geertsema proposes an analysis regarding the use of metaphor in the two traditions. ${ }^{48} \mathrm{He}$ defends the use of auditorial metaphor, derived from Jewish philosophy of Eugen Rosenstock-Huessy, Abraham Heschel, Buber, etc, to explain the process of knowing, ${ }^{49}$ while the proponents of correspondence theory uses an optical metaphor. It is a shift from Cartesian 'third person perspective' to a Judeo-Christian 'second person perspective'. This shift leads to a view of knowledge that emphasizes concrete situations or context, responsibility of knowing, and an attitude of attentiveness and respect to the created norms. Geertsema argues that an auditorial metaphor in epistemology can take a better account of everyday experience in thinking about Truth than the optical metaphors. The auditorial metaphor also suits the biblical view of truth better. ${ }^{50}$ The Biblical perspective of knowing also heightened our respect on the environment/nature for it is seen as an integral part of creation-as-meaning; it is not just a space waiting to be manipulated/valued/ imposed with human meaning. Biblical notion of creation requires us to see reality as an artwork, or a book written intentionally by an author, not a monkey. Biblical belief in creation requires us to think of reality as: 1 ) has

47 Lambert Zuidervaart, “Unfinished Business: Toward A Reformational Conception of Truth," in Philosophia Reformata (Nr. 74, 2009): 9.

48 See Henk Geertsema, "Knowledge Within the Context of Creation," in Faith and Philosophy Nr. 25 (2008).

49 Henk Geertsema, "Science and Person: Beyond the Cartesian Paradigm," in Studies in Science and Theology Vol. 7 (Aarhaus: Univ. of Aarhaus, 1999-2000): 62-63.

50 A Christian epistemology, in Reformational view, should conceive human knowing in the context of creation, it is less of a 'knowing from an atemporal viewpoint' - it is always an experience of knowing historically, from a certain limited perspective, mediated, and never autonomous. See also H. G. Geertsema, "Dooyeweerd on knowledge and truth," in Ways of Knowing in Concert, ed. J. Kok (Sioux Center: Dordt College Press, 2005), 85-100 
intrinsic meaning, 2) ever dependent on the Creator, 3) implies norms and commands. So, in this sense knowing reality is part of our responsibility and calling as creation.

The use of optical metaphors leads us to see knowing as seeing - with "mind's eyes". Knowing rationally liberates us from the evil of ignorance (e.g. limitation). Idea is not just idea but highest reality. This subject-object scheme of knowing/truth also has a potency of violence against 'the world out there' - because it is just an object to be known, to be named and tamed. In our thinking of it, we impose meaning/value on it. The use of optical metaphor leads to view of reality that is: 1) the static world of concept becomes absolute and more important than the (changing) 'reality itself', 2) the concentration on forms isolates the object from its environment (context), 3) simplify the rich diversity of reality to the sterile world of rationality and senses. ${ }^{51}$ The metaphor of hearing, in this regard, gives much more respect to the situatedness, temporality, and rich multi-aspectuality of reality. A command can be given to imply many different situations, yet must be conducted in each specific context. ${ }^{52}$

The 'hearing' metaphor does not separate knowing from acting (responsibly). Thinking is not conceived as projecting our rationality toward reality, on the contrary, human rational structures are conceived as already connected, situated within the reality from the beginning. We are created to be able to conceive reality meaningfully - otherwise knowledge won't be possible. So, knowing is start with primary connection. Being is co-determined with knowing and vice versa..$^{53}$ The metaphor of hearing also implies that we are spoken to. In this sense we are responsible in our response; being part of response-structure, we cannot avoid responding - to borrow Geertsema's term, we are homo respondens, and our response will be closing or opening the reality. ${ }^{54}$

\section{Comparison}

I suggest that there are some basic similarities and differences between Dooyeweerd and William James on the conception of Truth. I will list some similarities and differences and then I will try to launch a critique to William James' pragmatism from a Dooyeweerdian framework.

\footnotetext{
Geertsema, "Knowledge Within the Context of Creation," III.3.1.

Ibid., III.3.2.

Ibid.

Ibid., III.4.2.
} 


\section{Similarities}

The quite obvious similarity is that they are against a narrow definition of Truth as 'conformation of internal knowledge to external being'. The basis for this rejection is the naïve-ness of the underlying ontology assumed by this definition. James talks about the lack of rigor in the side of the Intellectualists in defining what they meant by 'agreement to reality' and 'reality itself'. In a more detailed analysis verifying the 'agreement' of our knowledge to 'reality' is lacking the means of comparison, because our knowledge of the external world is always mediated by our minds. In Dooyeweerd's conception, reality 'out there' is never independent to our existence. Being a tree for instance, implied being thought of by somebody, being economically acted upon by somebody, being owned or disowned by somebody, or being in one jurisdiction or another. In the correspondence model, criticized by both Dooyeweerd and James, a tree is just a heap of elements bounded together in some ways, forming a complex organic molecule called 'protein,' having the ability to reproduce themselves in some fixed patterns. When the tree happens to be useful, a luthier will cut it down, saw a plank out of it and craft a Spanish guitar. Then comes the aesthetic, economical, jural, and other properties imputed to the corpse of that dead tree now becoming an artifact. In a Dooyeweerdian model, that tree always having those kinds of aspects inherent in it being part of a creational structure. There even some normativity embedded in the 'law-side' of each 'thing' in the universe.

We can summarize the similarities between Dooyeweerd and James as: 1) Both are against 'naïve' realism's theory of correspondence, 2) Both are not against the existence of 'reality out there' but made a more careful analysis regarding its appearance in our consciousness. 3) Both are aware of the impossibility to compare our view of the external world and the world itself' because we lack the means to access the 'thing in itself' (Ding an sich). 4) Both are aware of the need to make our theoretical investigation relevant to everyday experience and put emphasize on concrete practices as verification of the theory (only in different sense). 5) Both have broader category for Truth than classical 'the agreement of thought to being' (adaequatio intellectus et rei).

\section{Incompatibility and Reflection}

Dooyeweerd anchored his analysis of Truth in a 'supra-modal', or to use his own often misunderstood term: 'supra-temporal', Archimedian point. In this model, Truth, although cannot be absolute, have a stable and beyond human anchor. I don't think James will agree with this. James talks about the criteria 
of verification as something 'useful'. These criteria have no anchor beyond our human experience-unable us to have accountability beyond fellow human beings and their/our interests. While James refused to define Truth in terms of faithfulness; Dooyeweerd, following Vollenhoven, was using 'stand in the truth' as main metaphor to describe it. ${ }^{55}$ James' commitment to refuse all connections with transcendent anchor for his philosophy will suffer somewhat similar difficulties with other philosophies of 'pretended autonomy,' namely: There will be no chance to be encountered with 'real other voice'. There will be no strong and stable normativity outside our contingencies. I have three critiques based on this point.

First, it will be impossible, for James, to deal adequately with the problem of human evil. In one side we have no space for a stable norm beside a vague sense of 'usefulness' or 'it works'; but in another side we have a certain sense of what is 'evil'. We cannot accept easily an 'evil but useful' option. Take for example a rational decision of optimizing a new cancer drug purely by economical considerations. If the marketing manager decide to put the price too high, the competitor will gain the market, but make it too low will reduce the prospective return. ${ }^{56}$ The manager in this example systematically excludes human misery and the pharmaceutical industry's ethical duty out of the equation. Hannah Arendt's famous 'banality of evil' mechanism has taken place here. Jamesian instrumentalism will face great difficulties and not so useful in this case.

Second, it will be also difficult to explain love and many selfless loving acts of the saints. I would say that James' Do-It-Yourself Truth-Making Company will be unable to explain satisfactorily the behavior of countless martyrs in their 'useless self-transcendent' ${ }^{57}$ acts of living 'the Way' unto their tragic ends. It is completely useless from immanent vantage point. I think Griffioen is right in making a necessary emphasize of what he calls 'the first kind of relations' - between human agents with 'heaven' or 'God' - not allowing it to be collapsed into three other kinds of relations, namely: relations with formal institutions, informal/'face-to-face' relations, and nature. ${ }^{58}$

Lastly, I'm thinking of James' absolutization of one modality, or perhaps some of them. James may not absolutize analytical aspect, but perhaps economic aspect that 'as long as it works to make us prosper and competitive, it is $\mathrm{OK}^{\prime}$, or biotic aspect that 'as long as it is useful for our survival,

55 Dooyeweerd, A New Critique of Theoretical Thought, Vol. 2, 571-572.

56 I took the example from Adam Morton's fine book, On Evil (NY: Routledge, 2004), 11-12.

57 I am borrowing Merold Westphal's term in his book Suspicion and Faith: The Religious Uses of Modern Atheism (Grand Rapids: Eerdmans, 1993).

58 From Lecture Notes "On Four Basic Relations," given in VU Amsterdam, November 3d, 2009. 
it is $\mathrm{OK}^{\prime}$, etc. In some way, pragmatism's absolutization is not fixed in one aspect; but since it doesn't accept the transcendent anchor point (the Origin) it will fall to idolize one of those creational aspects and it will close down the creation. Because both thinkers value highly everyday human experience (naïve experience in Dooyeweerd's term), it seems like a good platform to compare the two in history of concrete happenings. In that regard, I am sure Dooyeweerd's bold conviction on human rootedness in the Origin will win the day. But again, it is yet to be seen.

\section{Conclusion}

William James is better known than Dooyeweerd. I hope by comparing the two epistemologies, Reformational philosophy can have a better exposure and the reader can discover wider and deeper aspects of truth. James' and Dooyeweerd's starting points are widely different, despite some similarities in their attack toward naïve realism and Cartesian Correspondence epistemology. While Dooyeweerd explicitly states that his aim is to construct a framework of philosophy that is faithful to Christian ground-motives, James is quite explicitly not starting from a Christian faith - a secular thinker, if you prefer. So, it is rather natural that Dooyeweerd's system, albeit it's more resourceful in many ways, is not so easily understandable, let alone accepted by wider audience although more and more people realize his contribution nowadays. I think we need to implement Dooyeweerdian framework to today's highly complicated environment, rather than debating apologetically who is superior. In that case James' suggestion about verification seems to be very useful. 